\title{
Inactivation Effect of Standard and Fractionated Electron Beam Irradiation on Enveloped and Non-Enveloped Viruses in a Tendon Transplant Model
}

\author{
Tanja Schmidt ${ }^{a}$ Arnd T. Hoburg ${ }^{b}$ Uwe Gohs $^{c}$ Wolfgang Schumann ${ }^{d}$ \\ Jung-Won Sim-Brandenburg ${ }^{e} \quad$ Andreas Nitsche ${ }^{e} \quad$ Sven Scheffler $^{f} \quad$ Axel Pruss $^{g}$ \\ a Julius Wolff Institute, Center for Musculoskeletal Surgery, \\ ${ }^{\mathrm{b}}$ Sports Medicine \& Arthroscopy Service, Department for Orthopedic Surgery and Traumatology, Charité - Universitätsmedizin Berlin, \\ ${ }^{\mathrm{b}}$ Leibniz Institute of Polymer Research Dresden, \\ ${ }^{d}$ Gamma-Service Produktbestrahlung GmbH, Radeberg,

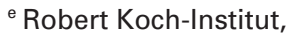 \\ ${ }^{f}$ Chirurgisch-Orthopädischer Praxis Verbund (COPV), \\ ${ }^{g}$ University Tissue Bank, Institute of Transfusion Medicine, Charité - Universitätsmedizin Berlin, Germany
}

\section{Keywords}

Allograft · Irradiation - Ebeam - Tissue sterilization .

Tissue bank

\section{Summary}

Background: For increasing allograft tendon safety in reconstructive surgery, an effective sterilization method achieving sterility assurance including viruses without impairing the grafts properties is needed. Fractionated Electron Beam (Ebeam) has shown promising in vitro results. The proof of sufficient virus inactivation is a central part of the process validation. Methods: The Ebeam irradiation of the investigated viruses was performed in an optimized manner (oxygen content $<0.1 \%,-78{ }^{\circ} \mathrm{C}$ ). Using principles of a tendon model the virus inactivation kinetics for HIV-2, HAV, pseudorabies virus (PRV) and porcine parvovirus (PPV) were calculated as $\mathrm{TCID}_{50} / \mathrm{ml}$ and $D_{10}$ value $(k G y)$ for the fractionated $(10 \times 3.4 \mathrm{kGy})$ and the standard $(1 \times 34$ kGy) Ebeam irradiation. Results: All viruses showed comparable $D_{10}$ values for both Ebeam treatments. For sufficient virus titer reduction of $4 \log _{10} \mathrm{TCID}_{50} / \mathrm{ml}$, a dose of $34 \mathrm{kGy}$ of the fractionated Ebeam irradiation was necessary in case of HIV-2, which was the most resistant virus investigated in this study. Conclusion: The fractionated and the standard Ebeam irradiation procedure revealed comparable and sufficient virus inactivation capacities. In combination with the known good biomechanical properties of fractionated Ebeam irradiated tendons, this method could be a safe and effective option for the terminal sterilization of soft tissue allografts.

\section{Schlüsselwörter \\ Allograft · Bestrahlung · Ebeam · Gewebesterilisierung Gewebebank}

\section{Zusammenfassung}

Hintergrund: Zur weiteren Erhöhung der Sicherheit von Sehnenallografts in der rekonstruktiven Sporttraumatologie und Orthopädie wurde mit der Elektronenstrahlbehandlung (Ebeam) eine effektive Sterilisationsmethode entwickelt, die höchstmögliche biologische Sicherheit ohne klinisch relevante Beeinträchtigung der Transplantateigenschaften bieten könnte. Der Nachweis einer hinreichenden Virusinaktivierung ist dabei zentraler Bestandteil der Prozessvalidierung. Methoden: In einem aus der Sehnenbestrahlung abgeleiteten Testmodell wurden folgende Viren untersucht: HIV-2, HAV, Pseudorabies-Virus (PRV) und Porcines Parvovirus (PPV). Die Elektronenstrahlbehandlung der untersuchten Virusstämme erfolgte unter optimierten Bedingungen (Sauerstoff-Gehalt von weniger als $0,1 \%,-78{ }^{\circ} \mathrm{C}$ ). Die fraktionierte Ebeam-Bestrahlung (10 Zyklen à 3,4 kGy) wurde mit der Ebeam-Standardbestrahlung (1 Zyklus à $34 \mathrm{kGy}$ ) hinsichtlich der Virusabreicherungskapazität $\left(\mathrm{TCID}_{50} / \mathrm{ml}\right)$ und der $D_{10}$-Werte ( $\left.k G y\right)$ verglichen. Ergebnisse: Alle Viren zeigten vergleichbare $D_{10}$-Werte für beide Ebeam-Bestrahlungen. Für eine ausreichende Virustiterreduktion von $4 \log _{10} T C D_{50} / \mathrm{ml}$ war für das resistenteste Virus (HIV-2) eine Dosis von 34 kGy fraktionierter Ebeam-Bestrahlung notwendig. Schlussfolgerung: Die fraktionierte Ebeam-Bestrahlung weist im Vergleich zum Standard-Ebeam-Verfahren eine vergleichbare und hohe $\mathrm{Vi}$ rusabreicherungskapazität auf. In Kombination mit den bekannt guten biomechanischen Eigenschaften von fraktioniert Ebeam-bestrahlten Sehnen könnte dieses Verfahren eine sichere und wirksame Option für die terminale Sterilisation von Sehnen- und Bandallografts sein.

\section{KARGER \\ Fax +497614520714 \\ Information@Karger.de}

www.karger.com (c) 2012 S. Karger GmbH, Freiburg

$1660-3796 / 12 / 0391-0029 \$ 38.00 / 0$

Accessible online at:

www.karger.com/tm
Prof. Dr. Axel Pruß

University Tissue Bank, Institute of Transfusion Medicine

Charité - Universitätsmedizin Berlin

Charitéplatz 1, 10117 Berlin, Germany

Tel. +49 30450 5-52142, Fax -25976

axel.pruss@charite.de 


\section{Introduction}

Human allogenic soft tissue has many indications in reconstructive surgery and its use has increased in many countries, especially for anterior cruciate ligament (ACL) reconstruction [1-3]. Compared to autografts, the main advantage is the lack of any donor side morbidity and the faster return to normal activity [4]. However, especially in Europe, the use of allografts is limited mainly due to the potential risk of disease transmission from the donor to the recipient [5] law restrictions, and an insufficient availability.

Although transplantation associated infections are rare, cases are indicated [6]. Simonds et al. [7] reported transmission of HIV-1 by organ and tissue transplantation in 7 cases. Buck [5] estimated the risk of HIV transmission from an unrecognized infected donor was approximately one in 1.6 million. Without any precautions like donor screening etc., the risk was estimated to be 1 in 161 . Because the danger increases with an increasing number of infected persons in a community, the possibility to transplant a tissue from an unrecognized donor for other infections might be much higher. For hepatitis $C$ it is estimated to be 1 in 421,000 in the USA [8]. With the implementation of EU directives 2004/23/EC and 2006/17/EC basic requirements of viral safety in tissue donation were defined in general. While serological tests (anti-HIV-1/2, anti-HCV, HBsAg, anti-HBc, TPHA) are mandatory, the nucleic acid testing (NAT) for the HIV, $\mathrm{HBV}$ and $\mathrm{HCV}$ is not explicitly required [11, 12]. Additional NAT screening in blood products shortens the diagnostic window period (the time from exposure to positivity) for HCV by 41-60 to 15-22 days. An analogous reduction of the diagnostic window is also possible for HIV, the most feared viral agent in blood banking. Investigations carried out by the Interorganizational Task Force on Nucleic Acid Amplification Testing of Blood Donors in the USA showed that implementing HIV NAT reduced the diagnostic window for HIV by $10-15$ days to approximately 10 days [13, 14]. But even serology and NAT in combination cannot close the window period completely. Furthermore, there is the risk of bacterial contamination during the procedure. In 2002 the Center for Disease Control in the USA reported 26 cases of bacterial infection associated with transplanted tissues from a particular donor which resulted in the death of 1 patient $[15,16]$.

In the past, many terminal sterilization methods for soft tissue transplants were tested to overcome these problems without finding a solution. Chemical treatment with ethylene oxide caused intra-articular inflammatory reactions, graft-tohost reactions, and clearly reduced biomechanical strength of the grafts. Thus, the ethylene oxide treatment was discarded for tendon sterilization $[17,18]$. Although the peracetic acid treatment is an established sterilization method of bone, dermis, amnion and fascia lata transplants with no evidence to impair the transplants properties, in ACL tendon grafts it has caused significantly reduced biomechanical strength and decreased remodeling activity in ACL tendon grafts in an in vivo animal model [19]. However, it is used for tendon sterilization in Germany, but less data are available of the clinical outcome of such treated grafts.

Currently, low-dose gamma irradiation $(\leq 25 \mathrm{kGy})$ is used mainly for ACL graft sterilization in the USA and parts of Europe which eliminates bacteria, fungi, and sensitive viruses, but not all pathogens [3]. For sufficient pathogen inactivation, including resistant viruses like parvovirus or HIV, a dose of more than $30 \mathrm{kGy}$ is needed [20, 21]. However, many studies demonstrated a dose-dependent reduction of the biomechanical properties if grafts were gamma irradiated with a dose beyond $20 \mathrm{kGy}$ [22-24]. Clinical studies found significantly increased failure rates even if grafts were sterilized with middle dose (20-25 kGy) of gamma irradiation $[25,26]$.

Electron Beam (Ebeam) is a high energy electron treatment which is currently used for sterilization of medical devices and in radiation therapy [27]. The impact should be comparable to gamma irradiation [28]. The main advantage compared to gamma irradiation is the shorter irradiation time and reduced dose variances during the processing. Thus, the dose application could be better controlled [29].

Recently, we investigated the impact of a high-dose Ebeam irradiation $(34 \mathrm{kGy})$ on the biological remodeling and the biomechanical properties of soft tissue allografts used for ACL reconstruction in an in vivo sheep model and found significantly reduced biomechanical properties up to 12 weeks (unpublished data). To reduce the detrimental effects, we tried to modify the irradiation procedure and investigated the fractionated application of the required overall dose in 10 cycles of $3.4 \mathrm{kGy}$ instead of $34 \mathrm{kGy}$ in one cycle in vitro. Fractionation is a common procedure in radiotherapy and results in a reduced damage of healthy tissue surrounding a tumor tissue. Thus, we analyzed the biomechanical properties of human patellar tendons after standard Ebeam (34 kGy), standard gamma $(34 \mathrm{kGy})$ and fractionated Ebeam $(10 \times 3.4 \mathrm{kGy})$ irradiation and found significantly higher biomechanical strength in the fractionated Ebeam treated grafts compared to standard Ebeam or gamma irradiated tendons [1]. This effect might be related to the reduced density of free radicals generated during the fractionated Ebeam procedure compared to the standard Ebeam irradiation. These radicals are suspected to cause protein and collagen damage and, therefore, to be responsible for the impairment of biomechanical properties of irradiated tissue [30-32]. These effects are called the secondary or indirect irradiation effects. Although, it is well known from radiotherapy that fractionation does not influence the efficiency of tumor cell elimination it is unclear, whether the fractionation of the dose input influences the inactivation curve of viruses.

To our knowledge, this is the first study investigating the virus inactivation by standard and fractionated Ebeam treat- 
ment. We hypothesized to find no differences in virus inactivation curves for both Ebeam procedures and proclaimed a comparable inactivation dose $\left(\mathrm{D}_{10}\right)$ as for standard gamma irradiation.

\section{Material and Methods}

Viruses

We investigated the following viruses: HIV-2, enveloped, Retroviridae, genus Lentivirus, strain lymphadenopathy-associated virus type 2 (LAV2) propagated in CEM cells [33], and HAV, non-enveloped, Picornaviridae, genus Hepatovirus; pseudorabies virus (PRV), Aujeszky's disease virus, enveloped, Herpesviridae, genus Varicellovirus) strain Bartha was used as a model virus for the human herpesviruses and porcine parvovirus (PPV, non-enveloped, Parvoviridae) as a model for the human parvovirus B19 (table 1).

\section{Cell Lines and Culture Media}

The following virus/cell systems were used; briefly: PRV / mink lung cells (ML); PPV / pig kidney cells (pK13); HAV / embryonic rhesus monkey kidney cells (Frhk-4) and HIV-2 /human T lymphocyte cells (Molt4/8). Dulbecco's modified Eagle's medium high glucose (Gibco) supplemented with $10 \%$ fetal calf serum (FCS) and glutamine $(0.5 \mathrm{mg} / \mathrm{ml})$ was used for all cells except for the Molt 4/8 cells which were grown in RPMI 1640 medium supplemented with $10 \%$ FCS and glutamine $(0.5 \mathrm{mg} / \mathrm{ml})$. The cells were cultured at $37{ }^{\circ} \mathrm{C}$ in a humidified atmosphere of $5 \% \mathrm{CO}_{2}$. All cell lines and viruses were obtained from stocks by the Robert Koch Institute, Berlin, and are registered and documented there.

\section{Preparation of Virus Stocks}

Virus stocks were prepared from the supernatant of cultured infected cells as described elsewhere [34]. Briefly, subconfluent cell monolayers in tissue culture flasks $\mathrm{T} 75$ were infected with the respective virus using a multiplicity of infection (moi) of $0.01-0.1$. Cell cultures showing a prominent cytopathogenic effect (CPE) were scraped off and subjected to 1-3 freeze-thaw cycles. In the case of HIV-infected MOLT 4/8 cells, 1 week after the infection cells were mixed with uninfected cells (1:1) and co-cultivated for 7 days. Cell debris was removed by centrifugation $(2,000 \mathrm{rpm}$, $10 \mathrm{~min}, 4^{\circ} \mathrm{C}$, Varifuge 3.0. R, Heraeus, Hanau, Germany), and aliquots of virus supernatant of $1 \mathrm{ml}$ were prepared. Tubes were completely filled with virus suspension and stored at $-70{ }^{\circ} \mathrm{C}$

\section{Irradiation Procedure}

Following the biomechanical experiments with tendon transplants, all samples were placed on a height-adjusted stage in a dry ice-filled styrofoam box, maintaining a temperature of about $-78{ }^{\circ} \mathrm{C}$ during transport and irradiation (fig. 1). This specific sample packaging fulfills the requirement of minimum overdose ratio during the electron treatment with $10 \mathrm{MeV}$ electrons in order to reduce the maximum applied dose during sterilization as well as the undesired impairing of biomechanical properties of the graft. The overdose ratio, the minimum dose, and the place of minimum dose were determined during a dose mapping study using alanine dosimeters. These alanine dosimeters were calibrated against the National Standard of National Physical Laboratory (Teddington, UK). The samples were transported in a transport container according to EN 829 (Deutsches Institut für Normung 1996) to the irradiation facility GSE 80 of Gamma Service Produktbestrahlungs GmbH (Radeberg, Germany).The sterilization was performed in two different ways. In the case of standard Ebeam, an absorbed dose of 3.4, 6.8, 10.2 kGy etc. up to
Table 1. Viruses and cell lines

\begin{tabular}{ll}
\hline Virus & Cell lines \\
\hline HIV-2, Retroviridae, enveloped, approximately $100 \mathrm{~nm}$ & human T lymphocyte cells, (Molt 4 clone 8) \\
PRV, Herpesviridae, enveloped, approximately $170 \mathrm{~nm}$ & minc-lung cells (ML) \\
HAV, Picornaviridae, non-enveloped, approximately $30 \mathrm{~nm}$ & embryonal rhesus monkey kidney cells (Frhk-4) \\
PPV, Parvoviridae, non-enveloped, approximately $10 \mathrm{~nm}$ & pig kidney cells (pK13) \\
\hline
\end{tabular}

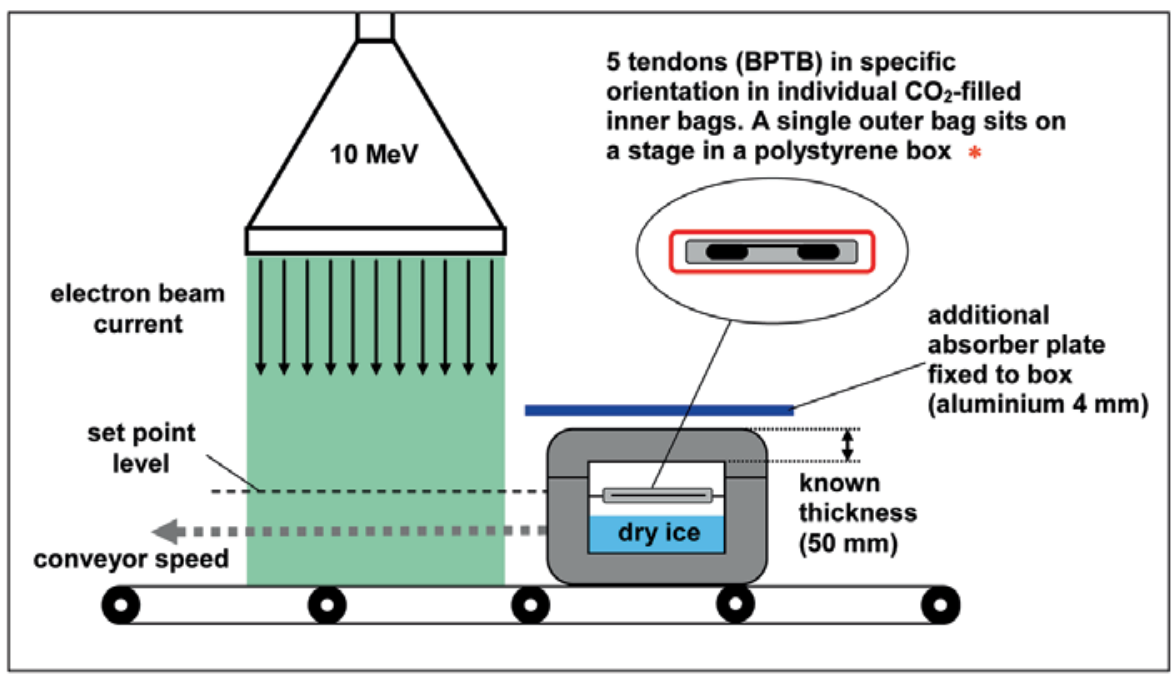

*instead of BPTB vials with virus suspensions were used, tubes were placed vertical in the box to ensure an equal irradiation exposure, each box contains two tubes of each virus ing and Ebeam irradiation process.
Transfus Med Hemother 2012;39:29-35 


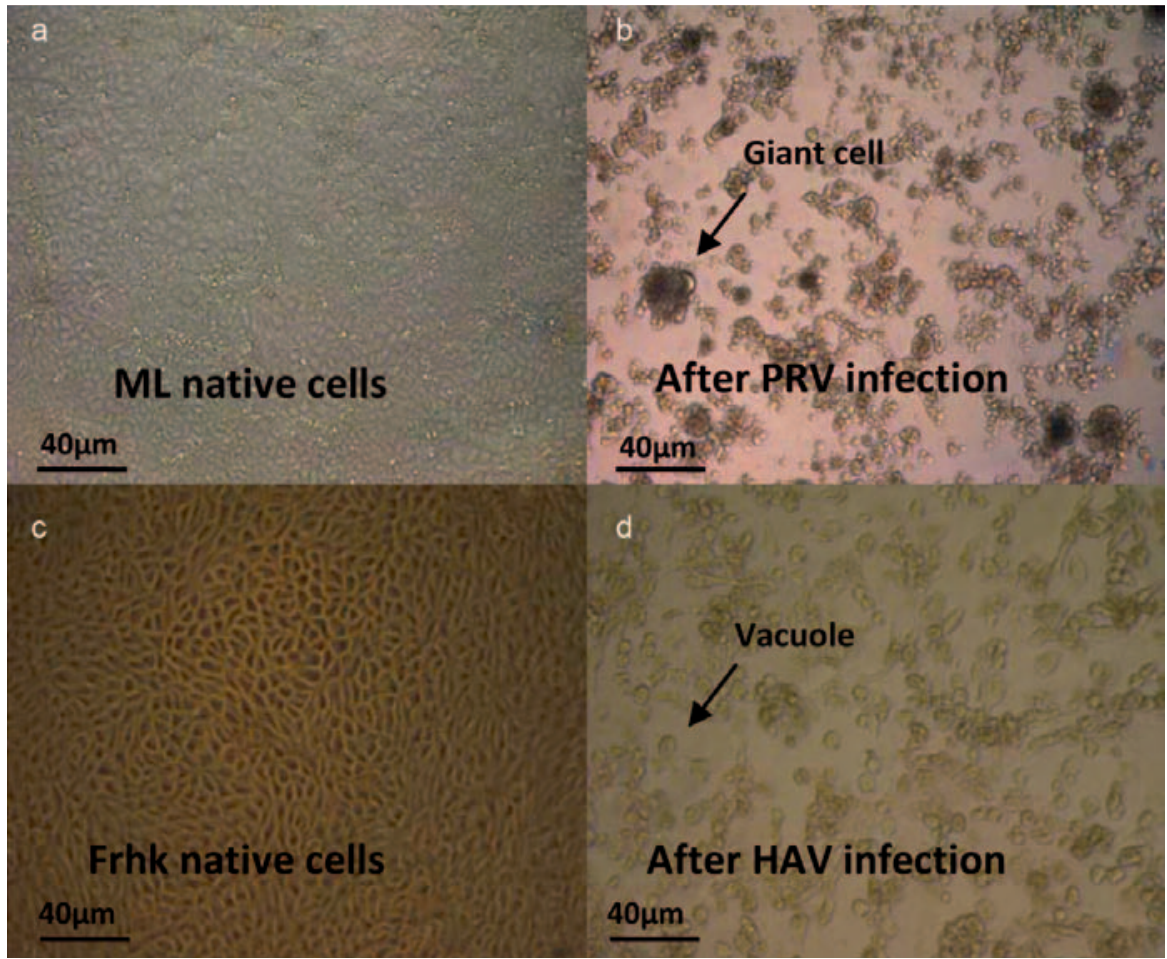

Fig. 2. Example of CPEs caused in cell culture by two of the investigated viruses evaluated by light microscopy. a ML native cells and $\mathbf{c}$ Frhk native cells in cell culture; typical CPE caused by virus infection with $\mathbf{b}$ PRV and $\mathbf{d}$ HAV such as cell lysis, vacuoles and giant cells (arrow).

Table 2. $\mathrm{D}_{10}$ values and dosages for $4 \log _{10}$ reduction for standard and fractionated ebeam irradiation

\begin{tabular}{|c|c|c|c|c|}
\hline \multirow[t]{2}{*}{ Virus } & \multicolumn{2}{|l|}{$\mathrm{D}_{10}$ value, $\mathrm{kGy}$} & \multicolumn{2}{|l|}{$4 \log _{10}, \mathrm{kGy}$} \\
\hline & standard Ebeam & fractionated Ebeam & standard Ebeam & fractionated Ebeam \\
\hline PRV & $5.6 \pm 0.4$ & $5.8 \pm 0.4$ & $20.8-24.0$ & $21.6-24.8$ \\
\hline HAV & $6.5 \pm 0.2$ & $5.9 \pm 0.2$ & $25.2-26.8$ & $22.8-24.4$ \\
\hline PPV & $8.6 \pm 0.6$ & $7.5 \pm 0.6$ & $32.0-36.8$ & $27.6-32.4$ \\
\hline HIV- 2 & $9.0 \pm 0.5$ & $8.0 \pm 0.5$ & $34.0-38.0$ & $30.0-34.0$ \\
\hline
\end{tabular}

$34 \mathrm{kGy}$ was applied in one treatment cycle. In the case of fractionated Ebeam, the required absorbed dose was applied in 1,2,3 etc. up to 10 cycles. The average dose of each cycle amounted to about $3.4 \mathrm{kGy}$. During the sterilization procedure, the absorbed dose was controlled via conveyor speed and electron current. The maximum deviation from the required minimum dose amounted to $\pm 1.4 \%$ for fractionated Ebeam and $\pm 3.0 \%$ for standard Ebeam. After sterilization, the samples were stored and transported in the polystyrene boxes with dry ice at $-78{ }^{\circ} \mathrm{C}$ to the virological laboratory and stored at $-80{ }^{\circ} \mathrm{C}$ until virus titration was performed. As titration and incubating control, one sample of each virus was transported and stored in same way as the other samples without being irradiated.

\section{Virus Titration}

Virus titer was determined as described elsewhere $[34,35]$. Briefly, cells were seeded 1 day before the viral assay in 96 -well plates containing $1.5 \times$ $10^{4}$ cells in cell culture medium per well. 10-fold serial dilutions were made from the samples in cell culture medium. $100 \mu \mathrm{l}$ of each dilution were pipetted into each of 12 wells in quadruplicate. The plates were incubated at $37{ }^{\circ} \mathrm{C}\left(5 \% \mathrm{CO}_{2}\right.$, saturated $\mathrm{H}_{2} \mathrm{O}$ atmosphere $)$ and observed by transmitted light microscopy over several days from always the same investigator until the virus control showed a CPE. An overview of some of the relevant CPEs in this study is given in figure 2. Before concluding evaluation, results were confirmed by a second qualified person. For
HIV-2, $100 \mu \mathrm{l}$ of cell suspension were transferred to new 96-well microtiter plate after 7 days and $100 \mu$ of fresh medium were added to each culture. The infectivity titers expressed as tissue culture infectious dose $\left(\mathrm{TCID}_{50} / \mathrm{ml}\right)$ were calculated according to Spearman and Kärber and Münch [36, 37]. The virus reduction factor (Ri) was calculated as described by Löwer [38].

Determination of Inactivation Dose $D_{10}$

The inactivation of viruses often approximates to an exponential relationship:

$$
N[D]=N_{0} \times 10^{\frac{D}{D_{10}}}
$$

$\mathrm{N}_{0}$ is the virus titer before and $\mathrm{N}[\mathrm{D}]$ the virus titer after irradiation with the absorbed dose D. $\mathrm{D}_{10}$ describes the required absorbed dose to reduce the initial virus titer to $10 \%$. This dose-response curve based on the assumption of a single-hit-single-target model

\section{Results}

The virus inactivation was evaluated in frozen suspensions to imitate the real production process in this experiment. The titer 

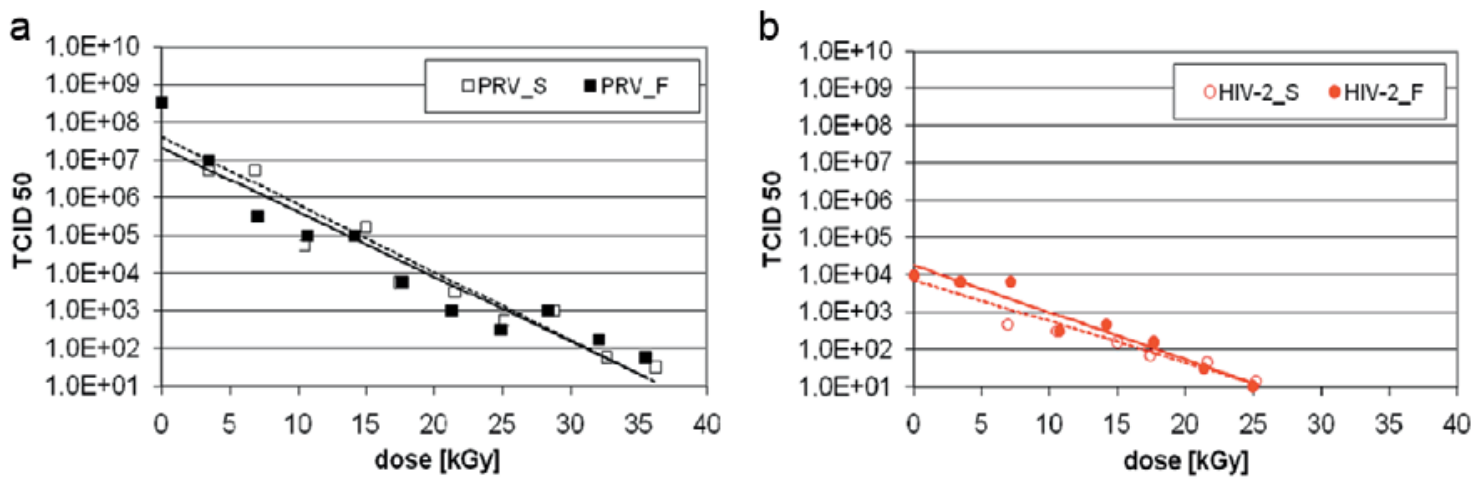

C

d

Fig. 3. Inactivation curves for standard and fractionated Ebeam treatment of the investigated viruses showed a linear relationship between the reduction factor and the observed dose. a PRV, b HIV-2, c PPV, d HAV.

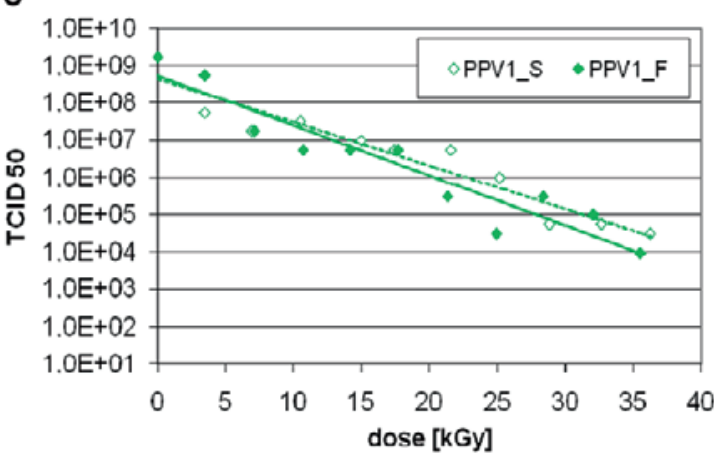

of the titration and incubation control served as reference. As expected, a linear relationship between the reduction factor and the absorbed dose was observed (fig. 3). The $\mathrm{D}_{10}$ values for the different viruses were calculated from the regression curve; from the $\mathrm{D}_{10}$ values, the irradiation dose needed to reduce the initial titer by $4 \log _{10}$ was determined (table 2 ).

We found no differences in the virus inactivation comparing fractionated and standard Ebeam treatment. For all investigated viruses, a reduction of the virus titer of at least $4 \log _{10}$ could be demonstrated. PRV showed the highest sensitivity (for standard Ebeam $\mathrm{D}_{10}=5.6 \pm 0.4 \mathrm{kGy}$ and for fractionated Ebeam $\mathrm{D}_{10}=5.8 \pm 0.4 \mathrm{kGy}$ ) to irradiation. HIV-2 was the most resistant virus investigated in this study (for standard Ebeam $\mathrm{D}_{10}=9.0 \pm 0.5 \mathrm{kGy}$ and for fractionated Ebeam $\mathrm{D}_{10}=8.0 \pm 0.5 \mathrm{kGy}$ ). Our results suggest that an irradiation dose of $34.0 \mathrm{kGy}$ of fractionated Ebeam irradiation achieves a sufficient reduction of the initial virus titer by $4 \log _{10}$ steps also for the most resistant virus.

\section{Discussion}

The use of allograft tendons for ACL replacement has significantly increased during the last decades due to their advantages compared to autografts, e.g. lack of any donor side morbidity, a faster return to daily living activities, a shorter operation time, and a reduced scarring [3]. However, the main disadvantage is the danger of disease transmission from the donor to the recipient.
Although basic safety procedures like serological and NAT screening for markers of virus infections and a donor risk analysis are performed [3] the danger of disease transmission cannot be excluded because of the window period in which an early infection, for example with HIV, could not be detected although tissue might be infectious.

Existing sterilization methods like gamma irradiation show dose-dependent tissue damaging effects [26].

The development of a terminal sterilization method which achieves a sufficient pathogen inactivation without impairing the biomechanical properties of the graft would provide an added safety to allograft tissue for transplantation. As an additional safety tool we investigated Ebeam irradiation in vitro and found favorable biomechanical results which could be improved further if the required absorbed dose of $34 \mathrm{kGy}$ was applied in 10 cycles of $3.4 \mathrm{kGy}[1,12]$.

This study aimed to investigate the virus inactivation by a standard and a fractionated Ebeam sterilization. We found no differences between these two proceedings. Both methods achieved a sufficient $4 \log _{10}$ titer reduction for all 4 viruses investigated in this study if a dose of $34-38 \mathrm{kGy}$ was used. Fractionation of the required minimum absorbed dose seemed to have no influence on the virus inactivation. Grieb et al. [32] assumed that pathogen inactivation is caused mainly by the direct disruption of the genetic material because of the applicated irradiation energy, the so called the direct or primary irradiation effects. In contrast protein/collagen damage is mainly caused by interactions with indirectly formed free radicals during the irradiation procedure what is called the indi- 
rect or secondary irradiation effects [31, 32]. That supports our findings of the improved biomechanical properties of the grafts and the unchained virus inactivation after fractionated Ebeam irradiation compared to standard Ebeam treatment.

Furthermore, the evaluated $\mathrm{D}_{10}$ values coincide with the results of other studies, which investigated the virus inactivation by gamma irradiation. It confirms the findings from Seto et al. [28, 40] and Dziedzic-Goclawska et al. [31] who proclaimed a comparable impact of Ebeam and gamma irradiation. HIV-2 was the most resistant virus in this study what seems to be contrary to the results of Pruss et al. [20] where the investigated parvovirus was the most resistant virus. Taking into account the experimental uncertainties of the inactivation dose $\mathrm{D}_{10}$ in both studies, comparable values for all viruses were determined. Minor changes could depend on the different models. Pruss et al. [20] placed the virus directly in a cortical bone diaphysis, and instead of porcine parvovirus they investigated the bovine parvovirus [31].

The main disadvantage of Ebeam irradiation is the limited penetration depth, which depends on the used energy, the atomic number of the absorbing product, and its density. In water (density $1 \mathrm{~g} / \mathrm{cm}^{3}$ ) the penetration depth of $10 \mathrm{MeV}$ electrons amounts to about $6 \mathrm{~cm}$ which is deep enough for soft tissue grafts. Therefore, Ebeam irradiation is useful for tissue grafts. In the case of sterilization of larger bone grafts, twosided sterilization should be used in order to fulfill the requirements of penetration depth

One limitation of this study is that we investigated virus suspensions. Hence, protecting interaction with organic tissue matrix could not be evaluated. Grieb et al. [41], however, found no differences in virus inactivation if pulverized tissue mixed with pathogen or virus suspension was used. They con- cluded that the organic matrix did not protect the pathogens from inactivation. Nevertheless, it remains unclear what happens if pathogen is incorporated in vital tissue as in a tissue graft from an infected donor. Further studies should focus on that to exclude that sterilization assurance level is influenced by organic matrix-pathogen interactions.

\section{Conclusion}

To conclude, comparable virus inactivation and inactivation dose values $\left(\mathrm{D}_{10}\right)$ were determined for both Ebeam procedures. The superior biomechanical in vitro results using the fractionated Ebeam process compared to standard Ebeam or gamma treatment suggest that this novel procedure is a safe and effective terminal sterilization method which achieves full pathogen inactivation without impairing the biomechanical properties of soft tissue grafts like tendons and ligaments. However, the biological effects must be confirmed in an animal model before it can be used for human graft sterilization.

\section{Acknowledgements}

We would like to thank Dr. Schwebke and Dr. Adlhoch from the Robert Koch Institute Berlin to provide the HAV, PPV and PRV stock solution and Mr. Bernd Schubarth for technical assistance.

\section{Disclosure Statement}

The authors declared no conflict of interest.

\section{References}

1 Hoburg A, Keshlaf S, Schmidt T, Smith M, Gohs $\mathrm{U}$, Perka C, et al: Fractionation of high-dose electron beam irradiation of BPTB grafts provides significantly improved viscoelastic and structural properties compared to standard gamma irradiation. Knee Surg Sports Traumatol Arthrosc 2011; 9:1955-1961.

2 McAllister DR, Joyce MJ, Mann BJ, Vangsness CT Jr: Allograft update: the current status of tissue regulation, procurement, processing, and sterilization. Am J Sports Med 2007;352:148-2158.

3 Cohen SB, Sekiya JK: Allograft safety in anterior cruciate ligament reconstruction. Clin Sports Med. 2007;26:597-605.

4 Kartus J, Movin T, Karlsson J: Donor-site morbidity and anterior knee problems after anterior cruciate ligament reconstruction using autografts. Arthroscopy 2001;17:971-980.

$\checkmark 5$ Buck BE, Malinin TI, Brown MD: Bone transplantation and human immunodeficiency virus. An estimate of risk of acquired immunodeficiency syndrome (AIDS). Clin Orthop Relat Res 1989;240: 129-136.
6 MMWR: Septic arthritis following anterior cruciate ligament reconstruction using tendon allografts-Florida and Louisiana, 2000. MMWR Morb Mortal Wkly Rep 2001;50:1081-1083.

7 Simonds RJ, Holmberg SD, Hurwitz RL, Coleman TR, Bottenfield S, Conley LJ, et al: Transmission of human immunodeficiency virus type 1 from a seronegative organ and tissue donor. N Engl J Med 1992;326:726-732.

8 Zou S, Dodd RY, Stramer SL, Strong DM; Tissue Safety Study Group: Probability of viremia with HBV, HCV, HIV, and HTLV among tissue donors in the United States. N Engl J Med 2004;351:751759

9 European Union, Commission Directive 2004/23/ EC Setting standards of quality and safety for the donation, procurement, testing, processing, preservation, storage and distribution of human tissue and cells. Official Journal 2004;102:41-52.

10 European Union, Directive 2006/17/EC implementing Directive 2004/23/EC As regards certain technical requirements for the donation, procurement and testing of human tissues and cells. Official Journal 2006;102:41-52.
11 Pruss A, Caspari G, Krüger DH, Blümel J, Nübling CM, Gürtler L, et al: Tissue donation and virus safety: more nucleic acid amplification testing is needed. Transpl Infect Dis 2010;12:375-386.

12 Hoburg AT, Keshlaf S, Schmidt T, Smith M, Gohs U, Perka C, et al: Effect of electron beam irradiation on biomechanical properties of patellar tendon allografts in anterior cruciate ligament reconstruction. Am J Sports Med 2010;381134-1140.

13 Busch MP, Dodd RY: NAT and blood safety: what is the paradigm? Transfusion 2000;40:1157-1160.

14 Dodd RY, Notari EP, Stramer SL: Current prevalence and incidence of infectious disease markers and estimated window-period risk in the American Red Cross blood donor population. Transfusion 2002;42:975-979.

15 Kainer MA, Linden JV, Whaley DN, Holmes HT Jarvis WR, Jernigan DB, et al: Clostridium infections associated with musculoskeletal-tissue allografts. N Engl J Med 2004;350:2564-2571.

16 Balsly CR, Cotter AT, Williams LA, Gaskins BD, Moore MA, Wolfinbarger L Jr: Effect of low dose and moderate dose gamma irradiation on the mechanical properties of bone and soft tissue allografts. Cell Tissue Bank 2008;9:289-298. 
17 Roberts TS, Drez D Jr, McCarthy W, Paine R: Anterior cruciate ligament reconstruction using freeze-dried, ethylene oxide-sterilized, bone-patellar tendon-bone allografts. Two year results in thirty-six patients. Am J Sports Med 1991;19:35-41.

18 Jackson DW, Windler GE, Simon TM: Intraarticular reaction associated with the use of freeze-dried, ethylene oxide-sterilized bone-patella tendon-bone allografts in the reconstruction of the anterior cruciate ligament. Am J Sports Med 1990;18:1-10.

19 Dustmann M, Schmidt T, Gangey I, Unterhauser FN, Weiler A, Scheffler SU: The extracellular remodeling of free-soft-tissue autografts and allografts for reconstruction of the anterior cruciate ligament: a comparison study in a sheep model. Knee Surg Sports Traumatol Arthrosc 2008;16:360-369.

20 Pruss A, Kao M, Gohs U, Koscielny J, von Versen R, Pauli G: Effect of gamma irradiation on human cortical bone transplants contaminated with enveloped and non-enveloped viruses. Biologicals 2002; 30:125-133.

-21 Fideler BM, Vangsness CT, Jr., Moore T, Li Z, Rasheed S: Effects of gamma irradiation on the human immunodeficiency virus. A study in frozen human bone-patellar ligament-bone grafts obtained from infected cadavera. J Bone Joint Surg Am 1994;76:1032-1035.

22 Salehpour A, Butler DL, Proch FS, Schwartz HE, Feder SM, Doxey CM, et al: Dose-dependent response of gamma irradiation on mechanical properties and related biochemical composition of goat bone-patellar tendon-bone allografts. J Orthop Res 1995;13:898-906.

23 Schwartz HE, Matava MJ, Proch FS, Butler CA, Ratcliffe A, Levy M, et al: The effect of gamma irradiation on anterior cruciate ligament allograft biomechanical and biochemical properties in the caprine model at time zero and at 6 months after surgery. Am J Sports Med 2006;34:1747-1755.
24 Gibbons MJ, Butler DL, Grood ES, Bylski-Austrow DI, Levy MS, Noyes FR: Effects of gamma irradiation on the initial mechanical and material properties of goat bone-patellar tendon-bone allografts. J Orthop Res 1991;9:209-218.

25 Sun K, Tian SQ, Zhang JH, Xia CS, Zhang CL, Yu TB: ACL reconstruction with BPTB autograft and irradiated fresh frozen allograft. J Zhejiang Univ Sci B 2009;10:306-316.

26 Rappe M, Horodyski M, Meister K, Indelicato PA: Nonirradiated versus irradiated Achilles allograft: in vivo failure comparison. Am J Sports Med 2007; 35:1653-1658.

27 Gerbi BJ, Antolak JA, Deibel FC, Followill DS, Herman MG, Higgins PD, et al: Recommendations for clinical electron beam dosimetry: supplement to the recommendations of Task Group 25. Med Phys 2009;36:3239-3279.

28 Seto A, Gatt CJ Jr, Dunn MG: Radioprotection of tendon tissue via crosslinking and free radical scavenging. Clin Orthop Relat Res 2008;466:1788-1795.

29 Reid BD: The Sterways process: a new approach to inactivating viruses using gamma radiation. Biologicals 1998;26:125-129.

30 Akkus O, Belaney RM, Das P: Free radical scavenging alleviates the biomechanical impairment of gamma radiation sterilized bone tissue. J Orthop Res 2005;23:838-845.

31 Dziedzic-Goclawska A, Kaminski A, UhrynowskaTyszkiewicz I, Stachowicz W: Irradiation as a safety procedure in tissue banking. Cell Tissue Bank 2005;6:201-219.

32 Grieb T, Forng RY, Brown R, Owolabi T, Maddox E, McBain A, et al: Effective use of gamma irradiation for pathogen inactivation of monoclonal antibody preparations. Biologicals 2002;30:207-216.
33 L'age-Stehr J, Niedrig M, Gelderblom HR, SimBrandenburg JW, Urban-Schriefer M, Rieber EP, et al: Infection of the human monocytic cell line Mono Mac6 with human immunodeficiency virus types 1 and 2 results in long-term production of virus variants with increased cytopathogenicity for CD4+ T cells. J Virol 1990;64:3982-3987.

34 Scheidler A, Rokos K, Reuter T, Ebermann R, Pauli G: Inactivation of viruses by beta-propiolactone in human cryo poor plasma and IgG concentrates. Biologicals 1998;26:135-144.

35 Pruss A, Hansen A, Kao M, Gürtler L, Pauli G, Benedix F, et al: Comparision of the efficiancy of virus inactivation methods in allogeneic avital bone tissue transplants. Cell Tissue Bank 2001;2:201-215.

36 Spearman A, Kärber G: Biometrie; in CavalliSforza L (ed): Grundzüge biologisch-medizinischer Statistik. Stuttgart, Gustav Fischer, 1974.

37 Reed L, Münch HA: A simple method for estimating fifty percent endpoints. Am J Hyg 1938;27:493497.

38 Löwer J: Virological aspects of the quality control of biologicals: quantitative considerations. Dev Biol Stand 1991;75:221-226.

39 Kempner ES, Schlegel W: Size determination of enzymes by radiation inactivation. Anal Biochem 1979;92:2-10.

40 Seto A, Gatt CJ Jr, Dunn MG: Improved tendon radioprotection by combined cross-linking and free radical scavenging. Clin Orthop Relat Res 2009; 467:2994-3001.

41 Grieb TA, Forng RY, Bogdansky S, Ronholdt C, Parks B, Drohan WN, et al: High-dose gamma irradiation for soft tissue allografts: high margin of safety with biomechanical integrity. J Orthop Res 2006;24:1011- 1018 